\title{
Chinese Sate Controlling, Institutional Participation and Real Earnings Management
}

\author{
Cheng $\operatorname{Min}^{1}$ \\ ${ }^{1}$ SHU-UTS SILC Business School, Shanghai University, Shanghai, P. R. China \\ Correspondence: Cheng Min, 20 Chengzhong Rd., Jiading Dist., Shanghai 201800, P. R. China. Tel: \\ 86-135-6476-5596. E-mail: chengmin2007@ shu.edu.cn
}

Received: June 12, 2015

doi:10.5539/ijef.v7n9p255
Accepted: June 25, 2015

Online Published: August 25, 2015

URL: http://dx.doi.org/10.5539/ijef.v7n9p255

\begin{abstract}
Early studies have showed that institutional investors help improve corporate governance by reducing the level of earnings management. Based on recent new measurement of earnings management, this article further studies whether institutional investors can help curb earnings management through real activities manipulation. The results show levels of real earnings management in Chinese state-owned companies are significantly higher than those in non-state-owned companies. Thus it indicates institutional investors have inhibitory effect on real earnings management, but their roles in state-owned companies have been restricted to a certain extent. The conclusions of this research have meaningful instruction to corporate governance and reform of Chinese state-owned enterprises as well as reform of Chinese property rights system.
\end{abstract}

Keywords: state controlling, institutional investor, earnings management

\section{Introduction}

More than 70 percent of Chinese publicly listed companies are owned and controlled by the state. With the reform of shareholder structure and the resolution of longstanding institutional problem that hindered the development of the securities market, institutional investors have gradually played an important role in Chinese capital market. To further promote the reform of Chinese state-owned enterprises, we need to clarify the corporate governance role of institutional investors in Chinese state-owned companies. Although there are different opinions about governance role of institutional investors in theoretical and empirical research, many scholars have come to similar empirical conclusions that stated-owned companies have less incentive to manage earnings which improve corporate governance. At the same time they also find institutional investors is beneficial to the improvement of corporate governance, but the positive governance effects of institutional investors is limited in the state-owned company.

It is important to note that most earnings management literatures on the relationship between state-owned equity and institutional investors use accounting accruals and discretionary accruals to measure earnings management. This measurement was effective in the past. With rapid development of information and business, accruals measurement could not take a real picture of earnings managements. Accrual items are used to manage earnings from accounting technique approach, which will not change the internal economic activity and cash flows of enterprise. Because accruals are easier to manipulation, they are also easily detected by auditors and regulators. In the contrast with accruals measurement, in fact real activities are the main way in which companies manage earnings. Real activities of earnings management are less bound by auditing and supervision. They affect the company's cash flow and are often at the expense of the companies' long-term interests.

Roychowdhury (2006) found that due to the strengthening of supervision and continuous improvement of accounting rules, the space of managing earnings by using accrual items is getting smaller and smaller. Instead companies tend to manipulate real activity for earnings management. After that, a growing number of scholars believe that manipulation of earnings will be carried out in real activities. Earnings manipulation behavior through real activities has gradually become the new focus of academic research. Research and literature also shows that companies manage earnings using mutual replaceable alternatives of accrual items and real activities.

From January 1, 2006, China implements the new company law in which the provisions of civil compensation liabilities are added on false financial reports and audit failure. The terms of the relevant provision in new 
company law are stricter and tougher than the old company law. On the other hand, from January 1, 2007, Chinese listed companies are required to adopt new accounting standards that are convergent with international financial reporting standards. In general, Chinese companies are facing rapid changes in law environment and accounting standards imposed by regulations.

Then, it is necessary to ask whether changes in regulatory and institutional environment affect alternative selection of earnings management means. Will Chinese companies turn to more hidden means of real activities to manage earnings instead of easier accrual items? What are effects of state-owned equity and institutional investors on real earnings management? Examinations of these questions will help us further understand corporate governance roles of state-owned equity and institutional investors. Kim and Sohn (2009) conclude that earnings management lead to increasing information uncertainty for external investors. Especially as terms as resources allocation, real earnings managements bring much more serious consequences than accrual items. It is likely for real earnings managements to change normal business activities of enterprises and damage companies' long-term interests. Finally, they will lead to net loss of social welfare. It is of great importance to study corporate governance roles of state-owned equity and institutional investors based on real earnings managements.

This paper contributes to earnings management literature mainly in the following two aspects: first, the study finds that the level of real earnings management in the state-owned holding companies is significantly higher than that in non-state-owned companies, which conflicts with previous research conclusion that state-owned holdings can restrain earnings management; Second, whether in state-owned companies or in non-state-owned companies, institutional investors can effectively restrain the real activities of earnings management. This result indirectly supports corporate governance role of institutional investors.

This article is arranged in seven sections. Section 2 is literature review and hypothesis development. Section 3 constructs research models. Section 4 is sample selection and descriptive statistics. Section 5 presents and explains regression results. Section 6 is robustness test. Section 7 concludes the research.

\section{Literature Review and Hypotheses Development}

\subsection{Literature Review}

Because of Chinese special institutional background, study of state-owned shares and earnings management is aimed at Chinese companies. Aharony etc. (2000) think that Chinese state-owned companies have the preference and privilege of being listed in public markets out of political purposes rather than of economic reasons. Therefore, the state-owned and non-state-owned companies have different motivations of earnings management, which determine their earnings management level. Empirical studies of many Chinese scholars have reached consistent conclusion that state-owned controlling can reduce earnings management.

Guang-yong lei, etc. (2006) found that when state-owned shares own the ultimate control right, the companies' level of earnings manipulation is low. Liang Sun etc. (2008) also earnings management level of non-state-owned companies was significantly higher than that of state-owned listed companies. Gao Yan (2008) also found when non-state-owned shares own the ultimate control right, listed companies have higher level of earnings management. From the perspective of accounting accruals earnings management, Xian-Hui Bo etc. (2009) studied governance performance of state-owned controlling. They found that positive earnings management level of state-owned holding companies was significantly lower than that of non-state-owned companies.

As for the impact of institutional investors on earnings management, early research literatures have also come to similar conclusions that the quality of accrual earnings is negatively related to the share proportion of short-term institutional investors. However, it's positively related to long-term institutional investors. Shu-qiang Cheng (2006) found that institutional investors take positive governance roles in Chinese companies by effectively restraining companies from earnings management. However Xian-Hui Bo etc. (2009) found that institutional investors are negatively related to the positive level of earnings management only in non-stated-owned companies. To some extent, that means institutional investors play a bigger governance role in non-state-owned companies.

So far, most research literature about the effect of state-owned holding and institutional investors on earnings management is based on accrual earnings management. But now more and more evidence shows that most companies manage eranings by means of real activities. Compared to the accrued items of earnings management mainly through accounting methods, real earnings management is used for some financial motives through managers' planned transactions deviating from the normal business operation.

Zang (2012) demonstrated that accruals and real activities are alternative ways to manage earnings.He also found 
that when the risks of litigation increase, the company will turn to real earnings management. Lin (2006) found that companies tend to use a series of ways to manage earnings (including real earnings management) to meet analysts' earnings forecasts goal. Cohen (2010) discovered before sarbanes-oxley enacted in 2002, companies' accruals earnings management steadily increased year by year. But after releasing of the bill accruals earnings management dropped significantly. On the contrary, real earnings managements tend to rise following previous decrease. This indicated that after the bill passed, ways of companies' earnings management are transformed from accruals to real activities.

Cohen et al. (2010) found that companies use both real activities and accruals to manage earnings before and after Second-Equity-Offerings. Chinese scholars also get similar evidence that Chinese listed companies as well use real activities of earnings management. Real activity of earnings management is not to adjust accounting accounts, but directly to manipulate economic activities. Therefore, it is difficult to distinguish the real activities manipulation from normal business operating activities. Compared to accruals earnings manipulation, real activities manipulation behavior is much more hidden. For real activities manipulation behavior, it is also difficult for external regulators to effectively play a role of auditing in lack of supervision standards. Thus, those real manipulations will not draw the attention of auditors and external regulators. Correspondingly, legal risks of real manipulations are not as much as those of accruals. However, real activities of earnings management often need external cooperation with related parties. Companies need to spend enough time to plan and complete real transactions with actual cash inflows and outflows. As a result, the implementation cost of real earnings management is relatively very high. And real activities manipulation behavior also causes long-term damage to those companies due to its really changed economic activities. But finally shareholders bear these costs and losses arising from earnings management, corporate management are less constrained by cost mechanism.

\subsection{Institutional Background and Hypotheses Development}

In China, for the purpose of political performance local government are deeply involved in the listing process of state-owned enterprises. Local government directly support expansions of state-owned listed companies by means of financial subsidies or tax reductions et al. In this situation, to gain financial support of local governments, state-owned companies are motivated to report higher earnings by financial frauds. Second, board chairmen or CEOs in charge of most state-owned listed companies are appointed by the governments. So these companies' performance has an important influence on managements' political future. Hence, in order to reduce their own political costs and improve levels of government status, management authorities of listed company also have strong motivation to report high earnings or carry out some accounting frauds. State-owned enterprises face more strict laws and regulation, more social attention, and more perfect enterprise financial systems. These conditions mean that for state-owned holding companies the cost of accrual earnings management is relatively much higher. Also indeed, some research shows that compared with non-state-owned holding companies, state-owned holding companies with accrual items manipulation have higher probability of getting non-standard auditing opinions. Therefore, state-owned enterprises much more tend to use real activities to manage earnings. On one hand, state-owned enterprises have severe insider control problems caused by the absence of ownership. Shareholders of state-owned enterprises execute less internal supervision of real activities. With weak internal monitoring, it is easy and secure for state-owned enterprises to use real activities earnings management. On the other hand, state-owned enterprises face more severe legal, regulatory and accounting system arrangement constraints; corporate management may be more inclined to alternative real earnings management instead of accounting accruals. Based on these analyses, this study puts forward the first research hypothesis.

\section{H1: Compared with private enterprises, state-owned holding companies are more inclined to use real earnings management instead of accounting accruals.}

Relative to individual investors, high holding of institutional investors cannot use traditional "Wall Street" selling to protect the value of their capital. If they sell their high holding of large stakes, it would be a great shock to the capital market. Therefore, in order to gain more monitoring benefits, institutional investors have an incentive to play a positive role in corporate supervision. In addition, institutional investors have the ability to play a positive role in corporate supervision for their professional analysis of listed companies. Thus, the increase in institutional investors holding will strengthen supervision from shareholders. Logically, their watchdog role can inhibit companies' real earnings management behavior. Based on this, this article puts forward the second hypothesis 2 :

\section{H2: The increase in institutional investors holding would help curb enterprise real activities earnings} management.

In state-owned companies, the state as controlling shareholders often uses state power to fulfill contracts with the 
other shareholders to protect their own interests. Because of lacking of internal supervision in state-owned companies, the agents of state-owned companies can use political forces to influence the running of the company, and for their own benefit exert control rights on other shareholders. Therefore, the influence of the other shareholders in state-owned company is smaller than in those non-state-owned companies. At the same time, because of the late development of Chinese institutional investors, their power is still very weak. Although institutional investors is known as another important external governance mechanism after control right markets, in Chinese state-owned companies are not yet enough to affect operation and management of state-owned companies. Therefore, institutional investors exert limited corporate government effects in state-owned companies. On this basis, we propose hypothesis 3 :

H3: The governance role that institutional investors play in state-owned companies is limited. With the shareholding increase of institutional investors, compared with those state-owned companies, Real earnings management in non-state-owned enterprises decreased more significantly.

\section{Model Specification and Sample Selection}

\subsection{Real Earnings Management Estimation Models}

In order to test these hypotheses, this paper first constructs the real activities manipulation models, and then builds multivariate regression test models. Roychowdhury (2006) pointed out that the real activities manipulations include: sales manipulation, production manipulation, and discretionary expenses manipulation. These three kinds of manipulation are measured by abnormal net cash flow from operating activities, abnormal production costs and discretionary expenses. Due to sales discount, sales manipulations reduce net operating cash flows resulting from sale of per unit. Mass production can reduce product cost per unit. But it can also increase the overall production cost and inventory holding cost; Cuts in research and development, advertising and daily expenses will lead to decrease in discretionary expenses. Therefore, if a company has highly managed earnings, it will exhibit lower net operating cash flows, higher production costs and lower discretionary expenses. After deducting normal part of earnings management measures, the company will have lower abnormal cash flow, higher abnormal production costs and lower abnormal discretionary expenses. This article uses net abnormal operating activities (CFO), abnormal production costs (PROD) and abnormal discretionary expenses (DISEXP) to measure levels of real earnings management (Roychowdhury, 2006; Cohen et al., 2008).

First, we run regressions by years and industries to estimate normal net operating cash flow, normal production cost and normal discretionary expenses. Then we get abnormal values of these three items by subtracting estimated value from real value. According to the Dechow (1995) research, the linear relationship between normal operating cash flow and sales can be calculated by regression function (1)

$$
\mathrm{CFO}_{i l} / \text { Asset }_{i t-1}=\beta_{0}+\beta_{1}\left(\text { I/Asset }_{i t-1}\right)+\beta_{2}\left(\text { Sale }_{i /} / \text { Asset }_{i t-1}\right)+\beta_{3}\left(\Delta \text { Sale }_{i} / \text { Asset }_{i t-1}\right)+\text { eit }
$$

Second, the production cost is the amount of cost of goods sold plus changes in inventory. the linear relationship between Cost of goods sold and current sales exists in regression function (2).

$$
\text { COGS }_{i /} / \text { Asset }_{i t-1}=\beta_{0}+\beta_{1}\left(1 / \text { Asset }_{i t-1}\right)+\beta_{2}\left(\text { Sale }_{i t} / \text { Asset }_{i t-1}\right)+\varepsilon_{i t}
$$

The linear relationship between inventory changes and current and previous sales changes exists in regression function (3).

$$
\Delta I N V_{i l} / \text { Asset }_{i t-1}=\beta_{0}+\beta_{1}\left(1 / \text { Asset }_{i t-1}\right)+\beta_{2}\left(\text { Sale }_{i l} / \text { Asset }_{i t-1}\right)+\beta_{3}\left(\Delta \text { Sale }_{i t-1} / \text { Asset }_{i t-1}\right)+\varepsilon_{i t}
$$

According to function (2) and (3), we use function (4) to estimate the normal production cost.

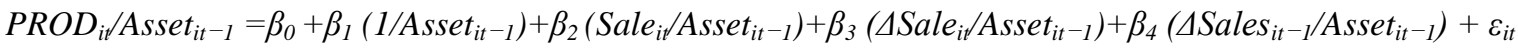

Finally, discretionary expenses include selling and administrative expense. The linear relationship

between discretionary expenses and sales of previous period exists in function (5). Through this function regression we can get normal discretionary expenses:

$$
\text { DISEXP }_{i t} / \text { Asset }_{i t-1}=\beta_{0}+\beta_{1}\left(1 / \text { Asset }_{i t-1}\right)+\beta_{2}\left(\text { Sale }_{i l} / \text { Asset }_{i t-1}\right)+\varepsilon_{i t}
$$

In the above formula, $\mathrm{CFO}_{\text {it }}$ represents net cash flow of operating activities for the company $\mathrm{i}$ in the year $\mathrm{t}$. Asset $_{i t^{-1}-1}$ is total assets for the company $\mathrm{i}$ in the year $\mathrm{t}-1$. Sit is total sales for the company $\mathrm{i}$ in the year $\mathrm{t} . \Delta$ Sales $_{\text {it }}$ is the changes in sales for the company $i$ from year $t-1$ to year t. PROD $_{i t}$ is the production cost including costs of goods sold and changes in the amount of inventory. DISEX $\mathrm{P}_{\mathrm{it}}$ is discretionary expenses including selling and administrative expenses. Abnormal operating cash flow $\mathrm{Ab}_{-} \mathrm{CFO}_{\mathrm{it}}$, abnormal production cost $\mathrm{Ab}_{-} \mathrm{PROD}_{\mathrm{it}}$ and abnormal discretionary expense $\mathrm{Ab} \_$DISEXP $\mathrm{it}_{\mathrm{it}}$ is the difference between the actual and estimated normal value.

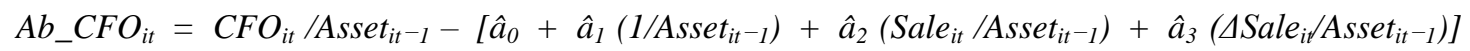




$$
\begin{gathered}
A b_{-} P R O D_{i t}=\operatorname{PROD}_{i t} / \text { Asset }_{i t-1}-\left[\hat{a}_{0}+\hat{a}_{1}\left(\text { I/Asset }_{i t-1}\right)+\hat{a}_{2}\left(\text { Sale }_{i t} / \text { Asset }_{i t-1}\right)+\right. \\
\left.\hat{a}_{3}\left(\Delta \text { Sale }_{i t} / \text { Asset }_{i t-1}\right)+\hat{a}_{4}\left(\text { SSale }_{i t-1} / \text { Asset }_{i t-1}\right)\right] \\
A b_{-} \text {DISEXP }_{i t}=\text { DISEXP }_{i t} / \text { Asset }_{i t-1}-\left[\hat{a}_{0}+\hat{a}_{1}\left(\text { I/Asset }_{i t-1}\right)+\hat{a}_{2}\left(\text { Sale }_{i t-1} / \text { Asset }_{i t-1}\right)\right]
\end{gathered}
$$

Because the company may carry on the real earnings management from several aspects at the same time, this article designs overall measurement of the real earnings management using the following function:

$$
A b_{-} E M=A b_{-} P R O D_{i t}-A b_{-} C F O_{i t}-A b_{-} D I S E X P_{i t}
$$

When the company uses real earnings management to make larger profits, this index is positive, whereas negative. The three measures of real earnings management individually have its unique information content. Therefore, this article will use both three individual indicators and a general index to measure real activity level of earnings management.

\subsection{Multivariate Regression Model}

In accordance with Barth (2008) and Cohen (2010) research literature, this article uses the following regression model 10 to examine hypothesis 1 (the definition of each variable is shown in table 1):

$$
Y_{i t}=\beta_{0}+\beta_{1} C O N T_{i t}+\beta_{2} M G T_{i t}+\beta_{3} R O A_{i t}+\beta_{4} L E V_{i t}+\beta_{5} B i g 4_{i t}+\beta_{6} S I Z E_{i t}+\beta_{7} \Delta C F_{i t}+\beta_{8} \text { Industry }+\varepsilon_{i t}
$$

$\mathrm{Y}_{\text {it }}$ represents real earnings management variables including Ab_CFO, Ab_PROD ,Ab_DISEXP and Ab_EM respectively. $\beta_{1}$ is the coefficient of state-controlled variable. $\beta_{2}$ is the coefficient of institutional ownership. According to hypothesis 1, relative to the non-state enterprises, state-owned companies have higher level of real earnings management. Hence we expect state-owned companies have lower operating cash flows, higher production costs and lower discretionary expenses. For the state-owned company samples, the value of abnormal operating cash flows, abnormal production cost and the abnormal discretionary expenses should be separately below, above and below the corresponding value of the non-state-owned samples. So in the regression model, $\beta_{1}$ coefficient would be negative, positive and negative respectively.

To examine Hypothesis 2, we construct model 11.

$$
Y_{i t}=\beta_{0}+\beta_{1} P I S_{i t}+\beta_{2} M G T_{i t}+\beta_{3} R O A_{i t}+\beta_{4} L E V_{i t}+\beta_{5} B i g 4_{i t}+\beta_{6} S I Z E_{i t}+\beta_{7} \Delta C F_{i t}+\beta_{8} \text { Industry }+\varepsilon_{i t}
$$

In Model 11, $Y_{\text {it }}$ represents real earnings management variables including Ab_CFO, Ab_PROD ,Ab_DISEXP and $\mathrm{Ab}$ EMM respectively. $\beta_{1}$ is the coefficient of institutional ownership.Similarly, according to the hypothesis 2 , with the increase of institutional investors holding, the level of real earnings management dropped significantly. Thus the abnormal operating cash flows, abnormal production cost and abnormal discretionary expenses will increase, reduce and increase respectively. Therefore, with all the sample, $\beta_{1}$ coefficient would be significantly positive, negative, positive, negative.

To examine Hypothesis 3, we construct model 12.

$$
\begin{gathered}
Y_{i t}=\beta_{0}+\beta_{1} C_{C O N T_{i t}}+\beta_{2} P I S_{i t}+\beta_{3} C O N T_{i t} * P I S_{i t}+\beta_{4} M G T_{i t}+\beta_{5} R O A_{i t}+\beta_{6} L E V_{i t}+\beta_{7} B i g 4_{i t}+ \\
\beta_{8} S I Z E_{i t}+\beta_{9} \triangle C F_{i t}+\beta_{10} \text { Industry }+\varepsilon_{i t}
\end{gathered}
$$

In Model 12, $\mathrm{Y}_{\mathrm{it}}$ still represents real earnings management variables including $\mathrm{Ab}$ _CFO, Ab_PROD ,Ab_DISEXP and Ab_EM respectively. According to hypothesis 3, with the increase in institutional investors holding, for non-state enterprises real earnings management level decreased more significantly. Therefore, when the sample is state-owned companies, $\beta_{3}$ coefficient would be significant or not. When the sample is state-owned enterprises, $\beta_{3}$ coefficient would be significantly negative, positive, negative and positive.

In the multivariate regression model, we also join a series of control variables in addition to independent variables. Because of the difference in the level of corporate debt, supervision strength from creditors is also different. Corporate debt level is one of our control variables. Most of executive compensation is related to corporate earnings. Management ownership affects interest alignments between the management and shareholders. Management compensation and shareholding are also controlled in the regression model. As a result, this regression model control financial leverage (LEV), management shareholding (MGT).Unlike accrued earnings management, real activity earnings managements affect companies' actual cash flow. so the regression model also control cash flow percentage change $(\triangle \mathrm{CF})$. In addition, the article also further controls the firm's return on assets (ROA), corporate SIZE (SIZE), the types of auditing opinion and so on. These factors will directly affect corporate earnings management to some extent. 
Table 1. Variables definition

\begin{tabular}{lll}
\hline Variable type & Variable & Symbol \\
\hline Dependent & Abnormal net cash flow of operating activities & Ab_CFO \\
Variable & Abnormal production cost & Ab_PROD \\
& Abnormal discretionary expense & Ab_DISEXP \\
& Summary level of total earnings management & Ab_EM \\
Indicator & Indicator variable to test H1.1 for state-controlled firms. Otherwise, 0. & CONT \\
Variable & Indicator variable to test H2. & PIS \\
& The proportion of institutional holding. & CONT* PIS \\
& Indicator variable to test H3. & MGT \\
Independent & Management shareholding & ROA \\
Variable & Return on assets & LEV \\
& Debt to asset ratio & Big4 \\
& Dummy variable.1 for firms audited by big 4, otherwise, 0. & SIZE \\
& natural logarithm of total asset & $\Delta$ CF \\
\hline
\end{tabular}

\section{Sample Selection and Descriptive Statistics}

In this article, all samples are selected from Chinese CSMAR database. We choose companies listed in Chinese main market from 2011 to 2013 and perform the following sample selecting processes: (1) to exclude companies without institutional participation; (2) to exclude companies with debt ratio greater than 1; (3) to eliminate companies in the financial industry; (4) to eliminate the industry with sample size less than 10. (5) To delete data sample with lack of variable value and incurrence of abnormal value.

With the above selecting standard, we get total 5200 sample companies distributed in 10 industries during 3 years from 2011 to 2013 exhibited in Table 2. State-owned company has 2361 samples, accounting for $45.4 \%$ of the total sample. It means that most of listed companies in China are state-owned. The proportion of state-owned companies is all above $40 \%$ during sample period. Institutional investors are participating in most of Chinese listed companies. Although institutional investors in China develop rapidly in recent years, the proportion of institutional holding is relatively much lower, less than $5 \%$ for almost $70 \%$ of sample companies.

Table 2. Sample distribution

\begin{tabular}{|c|c|c|c|c|}
\hline \multirow[t]{2}{*}{ Year } & \multirow[t]{2}{*}{ State controlling } & \multicolumn{2}{|c|}{ Institutional holding } & \multirow[t]{2}{*}{ Total } \\
\hline & & $\leqq 5 \%$ & $>5 \%$ & \\
\hline 2011 & $47 \%$ & $66.68 \%(1101)$ & $33.32 \%(550)$ & 1651 \\
\hline 2012 & $48 \%$ & $72.43 \%(1230)$ & $27.57 \%(468)$ & 1698 \\
\hline 2013 & $41 \%$ & $70.28 \%(1301)$ & $29.72 \%(550)$ & 1851 \\
\hline Total & $45.41 \%$ & $69.84 \%(3632)$ & $30.16 \%(1568)$ & 5200 \\
\hline
\end{tabular}

Table 3 reports the basic descriptive statistics results, the mean and median value of Ab_CFO are- 0.001 and -0 . 002 respectively. The maximum and the minimum are 2.892 and -2.172 respectively. The mean and median value of Ab_PROD are -0.005 and 0.004 respectively. The maximum and the minimum are 48.630 and -10.956 respectively. The mean and median value of $\mathrm{Ab} \_$DISEXP are 0.005 and -0.017 respectively. the maximum and the minimum are 8.470 and -0.454 respectively. The mean and median value of Ab_EM are-0. 011 and 0.019 respectively. The maximum and the minimum are 46.571 and -17.798 respectively.

From descriptive results, the maximum and the minimum of these four real earnings management variables are positive and negative respectively. The mean and median value of Ab_CFO are negative. Median Ab_DISEXP is negative. Median value of Ab_PROD and Ab_EM are positive. ALL these results are as we expected. Companies that manage earnings have lower abnormal cash flow, higher production cost and lower discretionary expenses. The data show that Chinese listed companies may have widespread behavior of real earnings management.

The minimum and maximum of institutional shareholding are 0 and 0.879 respectively. It shows that for Chinese listed companies great difference exists in attracting institutional investors. The average and median 
proportion of institutional holding is $4.8 \%$ and $3.2 \%$ respectively. Compared with state holding, Chinese institutional holding is much lower. Due to imbalanced development of Chinese listed companies, control variables distribution exhibits a greater difference. For example, Executives shareholding (MGT) shows a big gap. Average value of Executives shareholding (MGT) is low, average is $1.2 \%$, the median is 0, and the majority of listed companies have zero executives' shareholding. Larger differences also exist in Return on assets (ROA), financial leverage (LEV), SIZE and Cash flow rate $(\Delta \mathrm{CF})$. Financial statements of most Chinese companies are not audited by the big four auditing companies. On average, $6.1 \%$ of sample companies are audited by big four.

Table 3. Descriptive statistics of all variables

\begin{tabular}{lccccc}
\hline & Average & Median & Std.Dev & Min & Max \\
\hline Ab_CFO & -0.001 & -0.002 & 0.132 & -2.176 & 2.892 \\
Ab_PROD & -0.005 & 0.004 & 0.768 & -10.956 & 48.630 \\
Ab_DISEXP & 0.005 & -0.017 & 0.162 & -0.454 & 8.470 \\
Ab_EM & -0.011 & 0.019 & 0.820 & -17.798 & 46.571 \\
CONT & 0.454 & 0 & 0.497 & 0 & 1 \\
PIS & 0.048 & 0.032 & 0.050 & 0 & 0.879 \\
MGT & 0.012 & 0 & 0.170 & 0 & 0.321 \\
ROA & 0.046 & 0.040 & 0.073 & -0.937 & 1.560 \\
LEV & 3.691 & 2.191 & 5.640 & 0.087 & 141.245 \\
Big4 & 0.061 & 0 & 0.240 & 0 & 1 \\
SIZE & 22.035 & 21.837 & 1.301 & 18.147 & 28.482 \\
$\Delta$ CF & 0.038 & 0.004 & 15.095 & -696.964 & 836.540 \\
\hline
\end{tabular}

\section{Examination Results and Explanations}

Table 4 reports difference test in mean value of four earnings management dependent variable between state controlling and non-state controlling groups. For state-owned companies, Ab_CFO, Ab_PROD, Ab_DISEXP, Ab_EM average are - 0. 0012, 0. 016, 0.008 and 0.0092 respectively. In non-state-owned samples the average are $-0.0009,-0.003,0.001$ and -0.0031 respectively. The difference test results show that for state-owned companies Ab_CFO is significantly lower at 95\% confidence level, and Ab_PROD and Ab_EM are significantly greater at 99\% confidence level than those of non-state-owned companies. These results indicate that the level of real earnings management may be higher in non-state-owned companies.

Table 4. Group difference test in average value of earnings management

\begin{tabular}{lcccccccc}
\hline & \multicolumn{3}{c}{ State controlling } & \multicolumn{3}{c}{ non-state controlling } & \multicolumn{2}{c}{ Difference } \\
\cline { 2 - 9 } & $\mathrm{N}$ & Mean & Std. Dev & $\mathrm{N}$ & Mean & Std. Dev & Mean & T Value \\
\hline Ab_CFO & 2362 & -0.0012 & 0.013 & 2838 & -0.0009 & 0.021 & $-0.0003^{* * *}$ & -2.103 \\
Ab_PROD & 2362 & 0.016 & 0.094 & 2838 & -0.003 & 1.007 & $0.019^{* * *}$ & 2.982 \\
Ab_DISEXP & 2362 & 0.008 & 0.040 & 2838 & 0.001 & 0.014 & 0.007 & 1.398 \\
Ab_PROXY & 2362 & 0.0092 & 0.240 & 2838 & -0.0031 & 1.042 & $0.0123^{* * *}$ & 3.183 \\
\hline
\end{tabular}

Note. ${ }^{* * *}$ significant at the $1 \%$ level; ${ }^{* *}$ significant at the $5 \%$ level; ${ }^{*}$ significant at the $10 \%$ level.

Table 5 reports the correlation between dependent variables. Ab_PROD and Ab_DISEXP are significantly negatively correlated. This means that in addition to production control to increase current period profits, companies also undertake expense manipulations to reduce current discretionary expenses. Similarly, Ab_PROD and $\mathrm{Ab} \_\mathrm{CFO}$ are significantly negatively correlated, which suggests that the company may simultaneously exert both production control and sales control to manage earnings. Ab_DISEXP and Ab_CFO are significantly positively related, which indicates that the company may also manage earnings using both expense control and sales manipulation. Ab_EM is significantly negatively correlated with Ab_CFO, and is significantly positively correlated with Ab_PROD, and significantly negatively correlated with Ab_DISEXP. These results indicate that the overall measurement indicator (Ab_EM) for real earnings management is appropriately set as expected. When Ab_EM increases, companies manage earnings upward. 
Table 5. Pearson test of correlations matrix between dependent variables

\begin{tabular}{lcccc}
\hline & Ab_CFO & Ab_PROD & Ab_DISEXP & Ab_EM \\
\hline Ab_CFO & 1 & & & \\
Ab_PROD & $-0.180^{* * *}$ & 1 & & \\
Ab_DISEXP & $0.017^{* * *}$ & $-0.011^{* * *}$ & 1 & 1 \\
Ab_EM & $-0.332^{* * *}$ & $0.967^{* * *}$ & $-0.210^{* * *}$ & 1 \\
\hline
\end{tabular}

Note. ${ }^{* * *}$ significant at the $1 \%$ level; ${ }^{* *}$ significant at the $5 \%$ level; ${ }^{*}$ significant at the $10 \%$ level.

Table 6 reports the correlations between independent variables. Institution holding variable PIS is significantly negatively correlated with CONT and LEV. Variable PIS is significantly positively correlated with MGT, ROA and SIZE. These results suggest that institutional investors may prefer non-state-owned, low-debt and high-profitability and large-scale companies, which is consistent with the conclusions of existing research literature. These further show that institutional investors are more willing to invest companies with better performance, good corporate governance characteristics and faster growth. CONT is significantly negatively correlated with MGT, LEV and $\triangle \mathrm{CF}$, which means that state-owned companies have priority to issue equity resulting in lower financial leverage. Compared with non-state owned companies, Chinese state-owned companies also implement less management incentive and achieve poor cash flow performance. CONT is significantly positively correlated with ROA, Big4 and SIZE. This show that state-owned companies have better account performance, larger size and tend to recognize Big4 auditing. The correlations between other variables are more reasonable and intuitive. SIZE and ROA is significantly related, which shows that the larger the company, the better its profitability. LEV and ROA is significantly positively correlated, which indicates that the higher the financial leverage, the better its profitability. Although independent variables are significantly correlated, the test value of variance inflation factor is not greater than 5 . Therefore, the regression equation does not have serious multicollinearity problems.

Table 6. Pearson test of correlations matrix between independent variables

\begin{tabular}{|c|c|c|c|c|c|c|c|c|}
\hline & CONT & PIS & MGT & ROA & LEV & Big4 & SIZE & $\Delta C F$ \\
\hline CONT & 1 & & & & & & & \\
\hline PIS & $-0.004^{* * *}$ & 1 & & & & & & \\
\hline MGT & $-0.132^{* * *}$ & $0.007^{* * *}$ & 1 & & & & & \\
\hline ROA & $0.031^{* * *}$ & $0.167^{* * *}$ & $0.099^{* * *}$ & 1 & & & & \\
\hline LEV & $-0.037^{* * * *}$ & $-0.024^{* * *}$ & $0.258^{* * *}$ & $0.124^{* * *}$ & 1 & & & \\
\hline Big4 & $0.042^{* * *}$ & $-0.034^{* * *}$ & $-0.101^{* * *}$ & $0.015^{* * *}$ & $-0.068^{* * *}$ & 1 & & \\
\hline SIZE & $0.156^{* * *}$ & $0.010^{* * * *}$ & $-0.294^{* * * *}$ & $0.001^{* * *}$ & $-0.258^{* * *}$ & $0.399^{* * *}$ & 1 & \\
\hline$\Delta \mathbf{C F}$ & $-0.036^{* * *}$ & $-0.009^{* * *}$ & $-0.001^{* * *}$ & $0.011^{* * *}$ & $-0.001^{* * *}$ & $0.000^{* * *}$ & $-0.010^{* * * *}$ & 1 \\
\hline
\end{tabular}

Tables 7, 8 and 9 report multivariable regression results of the relationship between state shareholding, institutional holding and real earnings management. In Table 7 we analyze the impact of state shareholding on real earnings management. From the table, when real earnings management indicators are Ab_CFO, Ab_PROD and Ab_EM, regression coefficients of independent variable CONT are significantly negative, positive and positive. These regression results indicate that real earnings management level in state-owned company is significantly higher than that in non-state-owned companies. The results support hypothesis 1.

At the same time, we also examine the impact of institutional investors holding on real earnings management showed in table 8. In overall sample regression, the PIS coefficients of regression on four earnings management indicators (Ab_CFO, Ab_PROD, Ab_DISEXP and Ab_EM) were significant 0.01, $-0.23,0.077$ and -0.317 . These results show that the overall correlation between overall institutional investors holding and real earnings management is negative. Hence institutional ownership can to some extent inhibit real earnings management of Chinese listed companies. The regression results support hypothesis 2 .

Table 9 reports the different effect of institutional investors holding on real earnings management in state-owned and non-state-owned companies. In overall sample regression, the CONT* PIS coefficients of regression on four earnings management indicators (Ab_CFO, Ab_PROD, Ab_DISEXP and Ab_EM) were significant -0.056, $0.532,-0.189$ and 0.777 . The holding ratio of institutional investors is negatively related to the real earnings management. Although institutional investors in state-owned companies can also inhibit the management of real 
earnings management behavior, the supervisory role of institutional investors is significantly restricted. All these test results show that whether in state-owned companies or in non-state-owned companies, institutional investors holding has inhibitory effect on real earnings management. But in state-owned companies, the inhibitory effect of institutional holdings on real earnings management is relatively small. The results support hypothesis 3 .

Table 7. OLS regression results of state controlling on earnings management

\begin{tabular}{|c|c|c|c|c|c|c|c|c|}
\hline & \multicolumn{2}{|c|}{ Ab_CFO } & \multicolumn{2}{|c|}{ Ab_PROD } & \multicolumn{2}{|c|}{ Ab_DISEXP } & \multicolumn{2}{|c|}{ Ab_EM } \\
\hline & Coef. & T value & Coef. & T value & Coef. & T value & Coef. & T value \\
\hline Intercept & $-0.031^{*}$ & -1.883 & $-0.850^{* * *}$ & -3.949 & $-0.049^{* * *}$ & -1.989 & $-0.770^{* * *}$ & -3.351 \\
\hline CONT & $-0.002^{* * * *}$ & -2.581 & $0.063^{* * *}$ & 2.586 & 0.001 & 0.229 & $0.064^{* * *}$ & 2.636 \\
\hline MGT & $-0.024^{* *}$ & -2.040 & -0.034 & -0.484 & -0.011 & -0.768 & 0.001 & 0.012 \\
\hline ROA & $0.432^{* * *}$ & 17.768 & $-0.315^{* *}$ & -2.142 & 0.006 & 0.192 & $-0.752^{* * *}$ & -4.796 \\
\hline LEV & $0.001^{* * *}$ & 2.761 & -0.002 & -0.195 & $-0.001^{* *}$ & -1.932 & -0.002 & -0.080 \\
\hline Big4 & $0.016^{* *}$ & 2.040 & $-0.106^{* *}$ & -2.179 & $0.025^{* * *}$ & 2.466 & $-0.147^{* * *}$ & -2.835 \\
\hline SIZE & $0.003^{* *}$ & 2.293 & $0.041^{* * *}$ & 4.148 & $0.003^{* *}$ & 2.232 & $0.035^{* * *}$ & 3.600 \\
\hline$\Delta \mathrm{CF}$ & $0.001^{* * *}$ & 3.573 & $-0.002^{* * *}$ & -2.705 & -0.001 & -0.859 & $-0.002^{* * *}$ & -3.253 \\
\hline ADJ-R ${ }^{2}$ & \multicolumn{2}{|c|}{0.062} & \multicolumn{2}{|c|}{0.053} & \multicolumn{2}{|c|}{0.037} & \multicolumn{2}{|c|}{0.086} \\
\hline F Value & \multicolumn{2}{|c|}{$50.404^{* * * *}$} & \multicolumn{2}{|c|}{$4.676^{* * *}$} & \multicolumn{2}{|c|}{$3.127^{* * *}$} & \multicolumn{2}{|c|}{$24.346^{* * * *}$} \\
\hline Observations & \multicolumn{2}{|c|}{5200} & \multicolumn{2}{|c|}{5200} & \multicolumn{2}{|c|}{5200} & \multicolumn{2}{|c|}{5200} \\
\hline
\end{tabular}

Note. ${ }^{* * *}$ significant at the $1 \%$ level; ${ }^{* *}$ significant at the $5 \%$ level; ${ }^{*}$ significant at the $10 \%$ level.

Table 8. OLS regression results of institutional holding on earnings management

\begin{tabular}{|c|c|c|c|c|c|c|c|c|}
\hline & \multicolumn{2}{|c|}{ Ab_CFO } & \multicolumn{2}{|c|}{ Ab_PROD } & \multicolumn{2}{|c|}{ Ab_DISEXP } & \multicolumn{2}{|c|}{ Ab_EM } \\
\hline & Coef. & T value & Coef. & T value & Coef. & T value & Coef. & T value \\
\hline Intercept & $-0.035^{* *}$ & -1.913 & $-0.741^{* * *}$ & -3.513 & $-0.047^{* *}$ & -1.971 & $-0.659^{* * *}$ & -2.927 \\
\hline PIS & $0.010^{* * *}$ & 2.533 & $-0.230^{* *}$ & -2.042 & $0.077^{* * *}$ & 3.299 & $-0.317^{* * *}$ & -2.635 \\
\hline MGT & $-0.026^{* *}$ & -2.328 & 0.018 & 0.268 & -0.007 & -0.526 & 0.051 & 0.714 \\
\hline ROA & $0.430^{* * *}$ & 17.647 & $-0.259^{* * *}$ & -2.757 & -0.003 & -0.101 & $-0.685^{* * *}$ & -4.360 \\
\hline LEV & $0.001^{* * *}$ & 2.747 & -0.002 & -0.124 & $-0.001^{*}$ & -1.922 & -0.002 & -0.015 \\
\hline Big4 & $0.016^{* *}$ & 1.985 & $-0.098^{* *}$ & -2.010 & $0.021^{* *}$ & 2.098 & $-0.135^{* * *}$ & -2.598 \\
\hline SIZE & $0.001^{* * *}$ & 2.437 & $0.035^{* * *}$ & 3.672 & $0.002^{* *}$ & 2.109 & $0.032^{* * *}$ & 3.157 \\
\hline$\Delta \mathrm{CF}$ & $0.001^{* * *}$ & 3.565 & $-0.002^{* * *}$ & -2.666 & -0.001 & 0.885 & $-0.002^{* * *}$ & -3.221 \\
\hline ADJ-R ${ }^{2}$ & \multicolumn{2}{|c|}{0.062} & \multicolumn{2}{|c|}{0.043} & \multicolumn{2}{|c|}{0.052} & \multicolumn{2}{|c|}{0.091} \\
\hline F Value & \multicolumn{2}{|c|}{$50.399^{* * *}$} & \multicolumn{2}{|c|}{$4.337^{* * * *}$} & \multicolumn{2}{|c|}{$4.681^{* * *}$} & \multicolumn{2}{|c|}{$27.492^{* * *}$} \\
\hline Observations & \multicolumn{2}{|c|}{5200} & \multicolumn{2}{|c|}{5200} & \multicolumn{2}{|c|}{5200} & \multicolumn{2}{|c|}{5200} \\
\hline
\end{tabular}

Note. ${ }^{* * *}$ significant at the $1 \%$ level; ${ }^{* *}$ significant at the $5 \%$ level; ${ }^{*}$ significant at the $10 \%$ level.

Table 9. OLS regression results of state controlling, institutional holding on earnings management

\begin{tabular}{|c|c|c|c|c|c|c|c|c|}
\hline & \multicolumn{2}{|c|}{ Ab_CFO } & \multicolumn{2}{|c|}{ Ab_PROD } & \multicolumn{2}{|c|}{ Ab_DISEXP } & \multicolumn{2}{|c|}{ Ab_EM } \\
\hline & Coef. & T value & Coef. & T value & Coef. & T value & Coef. & T value \\
\hline Intercept & $-0.032^{* *}$ & -1.971 & $-0.837^{* * *}$ & -3.888 & $-0.053^{* *}$ & -2.201 & $-0.751^{* * *}$ & -3.270 \\
\hline CONT & $0.006^{* *}$ & 2.177 & $-0.095^{* * *}$ & -3.176 & $0.010^{* * * *}$ & 2.627 & $-0.111^{* * *}$ & -3.475 \\
\hline PIS & $0.050^{* * * *}$ & 2.392 & $-0.600^{* * *}$ & -2.764 & $0.217^{* * * *}$ & 4.820 & $-0.867^{* * *}$ & -3.741 \\
\hline CONT* PIS & $-0.056^{* *}$ & -2.330 & $0.532^{* *}$ & 2.103 & $-0.189^{* * *}$ & -3.616 & $0.777^{* * *}$ & 2.878 \\
\hline MGT & $-0.023^{* *}$ & -1.964 & -0.046 & -0.651 & -0.007 & -0.475 & -0.016 & -0.215 \\
\hline ROA & $0.428^{* * *}$ & 17.501 & $-0.266^{* * *}$ & -2.801 & -0.012 & -0.384 & $-0.683^{* * *}$ & -4.327 \\
\hline LEV & $0.001^{* * *}$ & 2.824 & -0.002 & -0.296 & $-0.001^{*}$ & -1.860 & -0.002 & -0.219 \\
\hline Big4 & $0.016^{* *}$ & 2.031 & $-0.100^{* *}$ & -2.059 & $0.023^{* *}$ & 2.259 & $-0.140^{* * *}$ & -2.683 \\
\hline SIZE & $0.001^{* * *}$ & 2.438 & $0.042^{* * *}$ & 4.246 & $0.002^{* *}$ & 2.062 & $0.039^{* * *}$ & 3.736 \\
\hline$\Delta \mathrm{CF}$ & $0.001^{* * *}$ & 3.571 & $-0.002^{* * *}$ & -2.708 & -0.001 & 0.865 & $-0.002^{* * *}$ & -3.260 \\
\hline ADJ-R ${ }^{2}$ & \multicolumn{2}{|c|}{0.062} & \multicolumn{2}{|c|}{0.063} & \multicolumn{2}{|c|}{0.071} & \multicolumn{2}{|c|}{0.081} \\
\hline F Value & \multicolumn{2}{|c|}{$39.426^{* * *}$} & \multicolumn{2}{|c|}{$4.517^{* * *}$} & \multicolumn{2}{|c|}{$5.126^{* * *}$} & \multicolumn{2}{|c|}{$27.323^{* * *}$} \\
\hline Observations & \multicolumn{2}{|c|}{5200} & \multicolumn{2}{|c|}{5200} & \multicolumn{2}{|c|}{5200} & \multicolumn{2}{|c|}{5200} \\
\hline
\end{tabular}

Note. ${ }^{* * *}$ significant at the $1 \%$ level; ${ }^{* *}$ significant at the $5 \%$ level; ${ }^{*}$ significant at the $10 \%$ level. 


\section{Conclusions}

This article contributes to previous research in that from the perspective of real earnings management we study the relationship between state controlling, institutional investors and earnings management. This article indirectly examines the governance effect of state holding and institutional investors holding. The main conclusions of this paper are as follows: firstly, in state-owned companies the level of real earnings management is significantly higher than that in non-state-owned companies. Hence state holdings are not beneficial to corporate governance. The conclusion is a supplementary correction of previous research results that state holdings are advantageous to corporate governance based on accrual earnings management. Secondly, on the whole, institutional ownership and real earnings management is significantly negative correlated, the higher the institutional investor shareholding, the lower the level of real earnings management. Thirdly, institutional investors can inhibit real earnings management behavior to a certain extent in both state-owned and non-state-owned companies. But in state-owned companies, the active governance effect of institutional investors is limited. In all, this article comes to conclusions that state holding are not good for corporate governance, and in state-owned companies institutional investors can effectively restrain earnings management behavior. These research results are complementary correction to existing governance role research of state holding, and also have important empirical value to reexamine the governance effect of state-owned companies.

According to research results of this article, we put forward the following suggestions in order to reduce the real earnings management behavior. First, it is necessary to further advance the reform of state-owned enterprises, the reform of ownership structure and property right reform as well. Promoting these reforms will reduce the controlling shareholder's stake, change the dominance of state-owned shares, and then effectively protect the legitimate rights and interests of minority shareholders. Second, we need vigorously develop institutional investors to effectively restrain the real earnings management.

\section{References}

Aharony, J., Lee, C. J., \& Wong, T. J. (2000). Financial Packaging of IPO Firms in China. Journal of Accounting Research, 38(1), 103-126. http://dx.doi.org/10.2307/2672924

Barclay, M., Holderness, C., \& Pontiff, J. (1993). Private Benefits from Block Ownership and Discounts on Closed-end Funds. Journal of Financial Economics, 33, 263-291. http://dx.doi.org/10.1016/0304-405X(93)90008-Y

Bushee, B. (1998). The influence of institutional investors on myopic R\&D investment behavior. The Accounting Review, 73, 305-333.

Carleton, W., Nelson, J., \& Weisbach, M. (1998). The influence of institutions on corporate governance through private negotiations: Evidence from TIAA-CREF. Journal of Finance, 53, 1335-1362. http://dx.doi.org/10.1111/0022-1082.00055

Chen, K., \& Yuan, H. (2005). Government Involvement, Market Forces, and the Pricing of Earnings: A Comparison of China's Tradable and Non-tradable Shares. Working Paper, Hong Kong University of Science and Technology.

Chen, K., Chen, C., Jin, Q., \& Yuan, H. (2009). Agency Problem and Liquidity Premium: Evidence from China's Stock Ownership Reform. Working Paper, Hong Kong University of Science and Technology.

Chen, K., Jin, Q., \& Yuan, H. (2006). Institutional Ownership, State Identity and Compensation Ratio: Evidences from China's Split Share Structure Reform. Working Paper. http://dx.doi.org/10.1596/1813-9450-4084

Chen, X., Harford, J., \& Li, K. (2007). Monitoring: Which Institutions Matter? Journal of Financial Economics, 86, 279-305. http://dx.doi.org/10.1016/j.jfineco.2006.09.005

Chen, Z., \& Xiong, P. (2001). Discounts on Illiquid Stocks: Evidences from China. Working Paper. http://dx.doi.org/10.2139/ssrn.286169

Cohen, D. A., \& Zarowin, P. (2010). Accrual-Based and Real Earnings Management Activities around Seasoned Equity Offerings. Journal of Accounting and Economics, 50(1), 2-19. http://dx.doi.org/10.1016/j.jacceco.2010.01.002

Cohen, D. A., Aiyesha, D., \& Lys, T. Z. (2008). Real and Accrual-Based Earnings Management in the Pre-and $\begin{array}{lllll}\text { Post-Sarbanes Oxley Periods. The Accounting Review, 83, } & \text { 757-787. }\end{array}$ http://dx.doi.org/10.2308/accr.2008.83.3.757 
Davis, G. F., \& Kim, E. H. (2007). Business ties and proxy voting by mutual funds. Journal of Financial Economics, 85, 552-270. http://dx.doi.org/10.1016/j.jfineco.2005.04.003

Fama, E., \& Jensen, M. (1983a). Agency Problems and Residual Claims. Journal of Law and Economics, 26, 327-349. http://dx.doi.org/10.1086/467038

Fama, E., \& Jensen, M. (1983b). Separation of Ownership and Control. Journal of Law and Economics, 26, 301-325. http://dx.doi.org/10.1086/467037

Firth, M., Chen, L., \& Zhou, H. (2009). Friend or Foe? The Role of State and Mutual Fund Ownership in the Split Share Structure Reform in China. Journal of Financial and Quantitative Analysis, forthcoming.

Francis, J., \& Philbrick, A. (1993). Analysts' Decisions as Products of a Multi-Task Environment. Journal of Accounting Research, 31, 216-231. http://dx.doi.org/10.2307/2491271

Gompers, P. A., \& Metrick, A. (2001). Institutional Investors and Equity Prices. Quarterly Journal of Economics, 116, 229-259. http://dx.doi.org/10.1162/003355301556392

Graham, J. R., Harvey, C. R., \& Rajgopal, S. (2005). The Economic Implications of Corporate Financial Reporting. Journal of Accounting and Economics, 40, 3-73. http://dx.doi.org/10.1016/j.jacceco.2005.01.002

Guercio, D., Dann, L., \& Partch, M. (2003). Governance and Boards of Directors in Closed-end Investment $\begin{array}{lllll}\text { Companies. Journal of Financial } & \text { Economics, } & 69, & 111-152 .\end{array}$ http://dx.doi.org/10.1016/S0304-405X(03)00110-7

Gunny, K. A. (2010). The Relation between Earnings Management Using Real Activities Manipulation and Future Performance: Evidence from Meeting Earnings Benchmarks. Contemporary Accounting Research, 27(3), 855-888. http://dx.doi.org/10.1111/j.1911-3846.2010.01029.x

Jiambalvo, J., Rajgopal, S., \& Venkatachalam, M. (2002). Institutional Ownership and the Extent to Which Stock Prices Reflect Future Earnings. Contemporary Accounting Research, 19, 117-145. http://dx.doi.org/10.1506/EQUA-NVJ9-E712-UKBJ

Ke, B., \& Ramalingegowda, S. (2005). Do Institutional Investors Exploit the Post-Earnings Announcement Drift? Journal of Accounting and Economics, 39, 25-53. http://dx.doi.org/10.1016/j.jacceco.2004.02.002

Kong, X., \& Tang, Y. (2008). Unitary boards and mutual fund governance. Journal of Financial Research, 31, 193-224. http://dx.doi.org/10.1111/j.1475-6803.2008.00237.x

Li, K., Wang, T., Cheung, Y., \& Jiang, P. (2009). Privatization and Risk Sharing: Evidence from the Split Share Structure Reform in China. Working Paper.

Li, Z., \& Sun, Z. (2009). Institutions, Governance and Accounting Research. Shanghai People Press.

MacKay, P., \& Wu, D. (2007). Redeemability as Governance Mechanism: A Study of Closed-end and Open-end Funds under Common Management. Working Paper, Hong Kong University of Science and Technology.

Mahoney, P. (2004). Manager-Investor Conflicts in Mutual Funds. The Journal of Economic Perspectives, 18(2), 161-182. http://dx.doi.org/10.1257/0895330041371231

McConnell, J., \& Servaes, H. (1990). Additional Evidence on Equity Ownership and Corporate Value. Journal of Financial Economics, 27, 595-612. http://dx.doi.org/10.1016/0304-405X(90)90069-C

Parrino, R., Sias, R., \& Starks, L. (2003). Voting with their feet: institutional ownership changes around forced $\begin{array}{lllll}\text { CEO turnover. Journal of Financial } & \text { Economics, }\end{array}$ http://dx.doi.org/10.1016/S0304-405X(02)00247-7

Pound, J. (1988). Proxy Contests and the Efficiency of Shareholder Oversight. Journal of Financial Economics, 20, 237-265. http://dx.doi.org/10.1016/0304-405X(88)90046-3

Qian, M. (2006). Whom Can You Trust? A Study of Mutual Fund Governance. Working Paper, National University of Singapore. http://dx.doi.org/10.2139/ssrn.685543

Roe, M. (1990). Political and Legal Restraints on Ownership and Control of Public Companies. Journal of Financial Economics, 27, 7-41. http://dx.doi.org/10.1016/0304-405X(90)90019-V

Romano, R. (1993). Public Pension Fund Activism in Corporate Governance Reconsidered. Columbia Law Review, 93, 795-853. http://dx.doi.org/10.2307/1122989

Roychowdhury, S. (2006). Earnings Management through Real Activities Manipulation. Journal of Accounting and Economics, 42, 335-370. http://dx.doi.org/10.1016/j.jacceco.2006.01.002 
Siew, H. T., Ivo, W., \& Wong, T. J. (1998). Earnings management and long-run market performance of initial public offerings. The Journal of Finance, 53(6), 1935-1984. http://dx.doi.org/10.1111/0022-1082.00079

Smith, M. (1996). Shareholder Activism by Institutional Investors: Evidence from CalPERS. Journal of Finance, 51, 227-252. http://dx.doi.org/10.1111/j.1540-6261.1996.tb05208.x

Wang, Y. (2010). Rent seeking by mutual fund managers: Evidence from equity contract renegotiations. Working Paper. http://dx.doi.org/10.1596/1813-9450-5422

Williams, C., \& Ryan, L. (2007). Courting Shareholders: The Ethical Implications of Altering Corporate Ownership Structures. Business Ethics Quarterly, 17(4), 669-688. http://dx.doi.org/10.5840/beq20071744

Woidtke, T. (2002). Agents watching agents? Evidence from pension fund ownership and firm value. Journal of Financial Economics, 63, 99-131. http://dx.doi.org/10.1016/S0304-405X(01)00091-5

Xin, Y., \& Xu, L. P. (2007). the Split Share Structure Reform, Corporate Governance, and Shareholder Protection. Economic Research Journal, 9, 121-133.

Zhang, M. (2006). Fund Governance, Fund Performance and Manager Turnover in China (Ph.D. dissertation). Shanghai University of Finance and Economics.

\section{Copyrights}

Copyright for this article is retained by the author(s), with first publication rights granted to the journal.

This is an open-access article distributed under the terms and conditions of the Creative Commons Attribution license (http://creativecommons.org/licenses/by/3.0/). 